\title{
SPIDERS (ARANEAE) AS A COMPONENT OF GROUND-DWELLING ANIMAL ASSEMBLAGES OF THE ENERGY CROP FIELDS IN NORTHERN BUKOVYNA (UKRAINE)
}

\author{
KATERYNA TYMCHUK ${ }^{1,2}$, NINA POLCHANINOVA ${ }^{3}$, ALINA ZHUK ${ }^{1}$, ULIANA LEHETA ${ }^{1}$, VOLODYMYR VOLOSHYN ${ }^{2}$, \\ MARIIA FEDORIAK $\otimes^{1}$
}

${ }^{1}$ Yuriy Fedkovych Chernivtsi National University, Kotsiyubynski Street 2, 58012, Chernivtsi, Ukraine; e-mail: m.fedoriak@chnu.edu.ua

${ }^{2}$ Bukovinian State Medical University, Theater Square 2, 58000, Chernivtsi, Ukraine; e-mail: katerynagavryliak@gmail.com

${ }^{3}$ V.N. Karazin Kharkiv National University, Svobody Square 4, 61022, Kharkiv, Ukraine; e-mail: n.polchaninova@karazin.ua

$\bowtie$ Corresponding author

Received: 1 May 2020 / Accepted: 8 November 2020

\begin{abstract}
Tymchuk K., Polchaninova N., Zhuk A., Leheta U., Voloshyn V., Fedoriak M.: Spiders (Araneae) as a component of ground-dwelling animal assemblages of the energy crop fields in northern Bukovyna (Ukraine). Ekológia (Bratislava), Vol. 40, No. 3, p. 240-247, 2021.

Energy cropping has positive effect only if considering and mitigating potential biodiversity loss in agroecosystems. While investigating grounddwelling animal assemblages in experimental fields of miscanthus and switchgrass in comparison with a legume-grass mixture and an abandoned field, we found low abundance and taxon diversity of the energy crops assemblages. Spiders comprised $3.3-3.8 \%$ of collected arthropods in the switchgrass and miscanthus and $8.3-10.1 \%$ in the abandoned field and grass mixture. Forty-seven spider species were collected: 14 species in the miscanthus field, 18 in the switchgrass, 23 in the grass mixture and 31 in the abandoned field. Spider diversity was the lowest in the miscanthus, while the number of specimens was minimal in the switchgrass. According to our findings, energy crops hosted poor spider assemblages with no species found exclusively in these habitats. To mitigate the negative impact of biofuel production on biodiversity, we recommend preserving areas of seminatural vegetation in the agricultural landscape.
\end{abstract}

Key words: spider diversity, habitat preference, bioindicators, biofuel, agroecosystems.

\section{Introduction}

Biomass crop production has advantages in terms of cost-effectiveness and carbon footprint and is seen as a mechanism for reducing climate risks (WWF Living Planet Report, 2016). However, the negative impact on biodiversity casts doubt on the resilience of such agroecosystems (Cook et al., 1991; Webb, Coates, 2012; Williams, Feest, 2019). The negative impact of energy crop cultivation on biodiversity depends on many abiotic and biotic factors and has spatial peculiarities. In particular, wood energy crops cause less impact on biodiversity than the arable ones; polycultural cultivation of native perennial species is likely to have a less significant negative impact on biodiversity than monocultural cultivation of annual energy crops (Groom et al., 2008; Dauber et al., 2010). Miscanthus (Miscanthus $\times$ giganteus JM Greef.) and switchgrass (Panicum virgatum L.) are among the most promising energy crops. They have wide adaptive capacity, can be grown effectively in various soil and climatic conditions of moderate latitudes, and provide high yields at minimal costs (Groom et al., 2008; Eggers et al., 2009; Energy Strategy of Ukraine..., 2017). Initially, energy crops were expected to become a relatively environmentally be- nign crop, since they require less fertilizers, pesticides and mechanical disturbances during a growing season (Lewandowski et al., 2003). Studies on vertebrate animals did not confirm it (Eggers et al., 2009), while the studies of the influence of perennial grassy energy crop production on individual arthropod groups or ground-dwelling animals in general are not sufficient for final conclusion (Holguin et al., 2010; Schaeffer et al., 2011; Dauber et al., 2015; Snelick, 2018; Williams, Feest, 2019).

Ukraine's Energy Strategy implies a dynamic growth in the use of biomass energy. However, associated zoological diversity on the plantations of energy crops in Ukraine remains outside the scope of researchers. Sporadic invertebrate researches in bioenergetic plantations relate, first of all, to the formation of agricultural pest entomocomplexes (Stefanovska et al., 2011, 2012; Sabluk et al., 2018). Taking into account the need to increase the area under cultivation of energy crops to achieve bioenergy goals, biodiversity analysis should be an important part of risk assessment measures (Dauber et al., 2010). The impact of second-generation bioenergetic plants on animal diversity in Ukraine is unstudied and belongs to the issues of significant relevance. 
Spiders are numerous generalist predators playing an important role in biological control in agroecosystems (Maloney et al., 2003; Benhadi-Marin et al., 2016; Michalko et al., 2019). They are widely used as bioindicators since their assemblage structures reflect anthropogenic and/or natural changes in environmental conditions (Cole et al., 2005; Blaum et al., 2009; Zhukov et al., 2018). Thus, they are a convenient group for the evaluation of ecosystem quality, which, in turn, promote biodiversity and ecosystem services.

The present research aimed at estimating diversity of spider assemblages in the miscanthus and switchgrass experimental fields in Northern Bukovyna in comparison with adjacent anthropogenic grasslands.

\section{Material and methods}

\section{Study site and sample plots}

The research was conducted on the lands of the Bukovyna State Agricultural Experimental Station of National Academy of Agrarian Sciences of Ukraine, located within administrative limits of the Ukraine's regional centre of Chernivtsi $(48.360717 \mathrm{~N}$, $25.933435 \mathrm{E}$ ). According to physiographic subdivision (National Atlas, 2007), Chernivtsi is situated on the border of two physiographic zones of Ukraine: the Ukrainian Carpathians and the deciduous forest zone.

We investigated two experimental fields of energy crops and two neighbouring fields with grassy vegetation for the comparison:

1. Study plot 1 - Control - an area that has not been cultivated since 2001, that is, an area of natural overgrowth. Poaceae predominate: Poa pratensis L., Dactylis glomerata L.; the other herbs are abundant - Trifolium repens L., Lotus corniculatus L., Stenactis annua (L.) Cass. ex Less. and Taraxacum officinale (L.) Weber ex F.H. Wigg; 0.25 ha.

2. Study plot 2 - Grass-legume mixture - a plot sown with a mixture of grasses for cattle and sheep feeding: Trifolium pratense L. + Medicago sativa L. + Bromus inermis Leyss. in the first year of cultivation without fertilizer; 0.2 ha.

3. Study plot 3 - Miscanthus - Miscanthus $\times$ giganteus J. M. Greef, Deuter ex Hodk., Renvoize in the fifth year of cultivation; planting rate of $1-3$ rhizomes $/ \mathrm{m}^{2} ; 0.1$ ha.

4. Study plot $4-$ Switchgrass - Panicum virgatum $\mathrm{L}$. in the fourth year of cultivation; 0.05 ha.

\section{Material collection}

The material was collected by pitfall trapping. The traps with a diameter of $7 \mathrm{~cm}$ were set up in a line at a distance $10 \mathrm{~m}$ from each other and filled on one third with ethylene glycol as a preservation. Traps were opened from April 5 to September 29, 2016, and were emptied twice a month.

This paper presents the results of analysis of spider assemblages during the entire time of trap exposure (176 days) and ground-dwelling animals during the early spring period (22 days, April 5-27, 2016). A total of 2224 individuals of vertebrate and invertebrate animals were collected in April 2016 and 3694 individuals of spiders (of which 2973 were mature) during the study period.

\section{Data analysis}

We assessed dynamic density of ground-dwelling animals (mainly arthropods) as a number of individuals per 10 trap-days (individuals/10 trap-days). The total spider dynamic density was calculated for the entire number of individuals collected at the relevant site during the study period. However, in the following analysis, we considered only adult spiders, because most juvenile individuals cannot be identified to the species level.

Dominance classes were determined after Stöcker and Bergmann (1977): eudominants - 31.7-100\% out of collected individuals, dominants - $10.1-31.6 \%$, subdominants $-3.2-10.0 \%$, recedents $-1.1-3.1 \%$ and subrecedents - less than $1.0 \%$.

Habitat fidelity indices for dominant species were calculated based on the proportion of individuals of a particular species in the samples at each plot and in total collection: $n_{i j} N-n_{i} N_{i} /\left(n_{i j} N+\right.$ $n_{i} N_{j}-2 n_{i j} N_{j}$ ), where $n_{i j}$ is the number of individuals of an $i$-species in the total sample $\left(\mathrm{N}_{\mathrm{j}}\right)$ at the corresponding study plot, and $n_{i}$ is the number of individuals of an $i$-species in the total collection of $\mathrm{N}$ individuals at all the plots studied (Pesenko, 1982).

Alpha-diversity of the spider assemblages was estimated based on Shannon index of species diversity, Pielou index of evenness and Simpson index of dominance (Magurran, 1991). These indices are widely used in ecological studies including biodiversity assessment of energy crops (Holguin et al., 2010; Platen et al., 2017; Williams, Feest, 2019), thus enabling consistent comparison with other researches. Calculations were performed in the program PAST (Hammer et al., 2001); differences between the index values were estimated by means of bootstrap analysis and visualized in the StatSoft Statistica 7.0 package.

Biocenotic similarity of the spider assemblages was assessed by the Renkonen index, $\mathrm{K}_{\mathrm{R}}=\sum \mathrm{min}\left(\mathrm{pi}_{1}, \mathrm{p}_{\mathrm{i} 2}\right)$, where $\mathrm{p}$ is the proportion of each species in the assemblage of $\mathrm{N}$ species (Jost et al., 2011). Faunistic similarity was assessed by the Sørensen index $\mathrm{K}_{\mathrm{S}}=2 \mathrm{C} / \mathrm{A}+\mathrm{B}$, where $\mathrm{C}$ is the number of common species in two assemblages of A and B species (Magurran, 1991).

Detrended correspondence analysis (DCA) of spider assemblages of the study plots was based on the species individual abundance. Only species represented by three or more individuals at two compared plots were taken into account. We chose two dimensions with eigenvalues and ordinated the results in the program PAST.

\section{Results}

\section{Spring assemblages of ground-dwelling animals}

Ground-dwelling animals in April collection were represented by 4 phyla, 7 classes and 13 orders. The number of animal orders at the study plots was as follows: control - 10, grass-legume mixture - 11, miscanthus - 8 and switchgrass - 7 (Fig. 1).

Rodents and terrestrial mollusks were collected only from the control plot while earthworms fall in traps in the agricultural fields (Fig. 2). Arthropods were distributed more evenly, except two orders (Lepidoptera and Homoptera) found at one plot out of four.

Arthropods' dynamic density in April was the highest at Contr (32.3 individuals/10 trap-days) and the lowest at Miscant (11.7 individuals/10 trap-days). The most abundant were the or- 


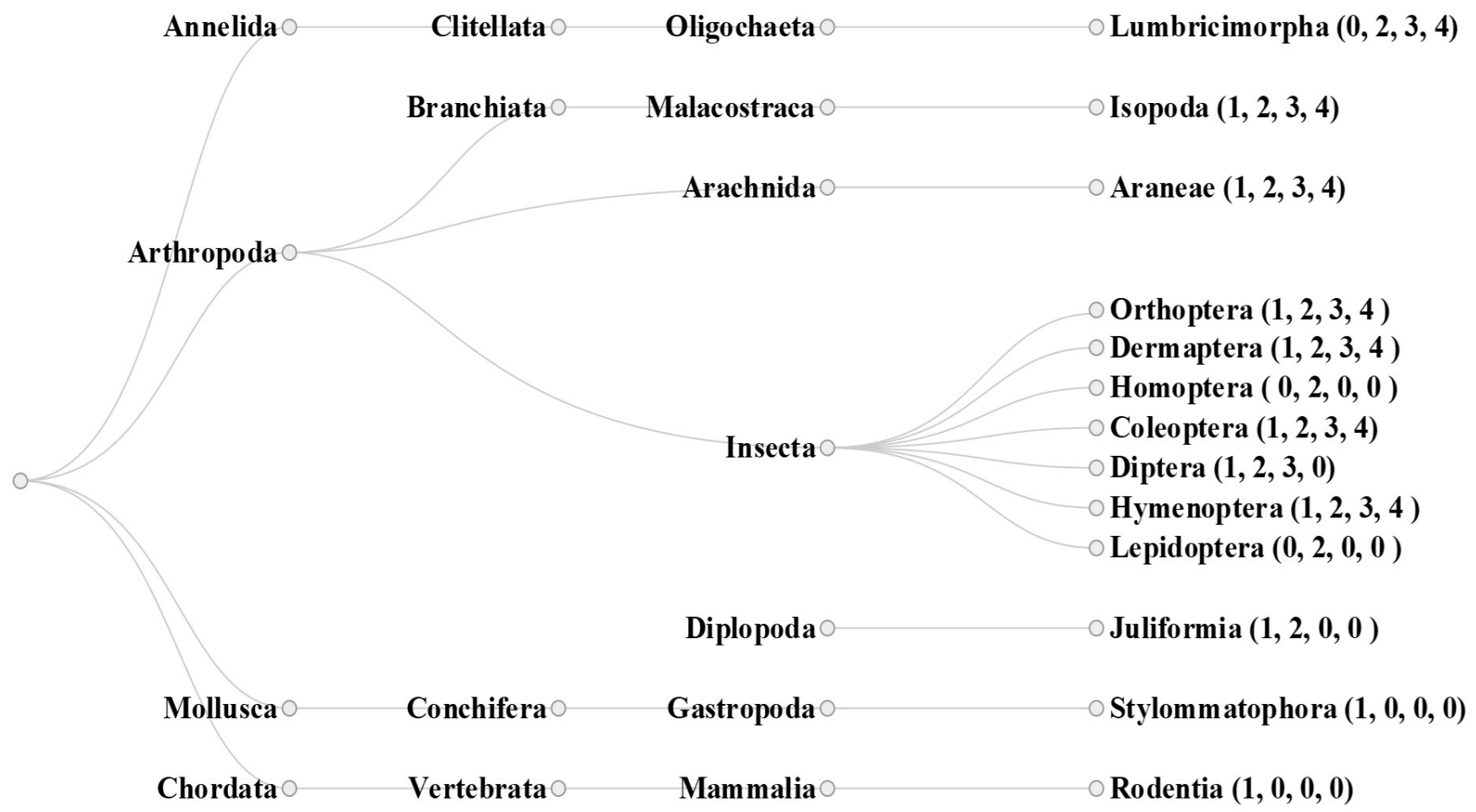

Fig. 1. Taxonomic structure of ground-dwelling animal assemblages at the study plots (April 2016).

Notes: 0 - no animals found; 1 - control plot; 2 - grass-legume mixture; 3 - miscanthus; 4 - switchgrass.

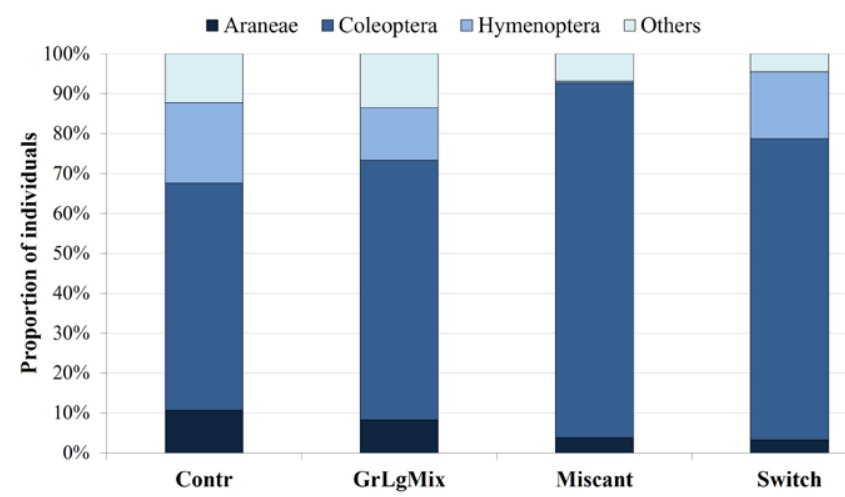

Fig. 2. Relative abundance of dominant orders of ground-dwelling arthropod assemblages at the study plots (April 2016).

Notes: Contr - control plot; GrLgMix - grass-legume mixture; Miscant - miscanthus; Switch - switchgrass.

Table 1. Faunistic and biocenotic similarity of spider assemblages at the study plots.

\begin{tabular}{|l|c|c|c|c|}
\hline & Contr & GrLgMix & Miscant & Switch \\
\hline Contr & & 0.42 & 0.36 & 0.29 \\
\hline GrLgMix & 0.66 & & 0.39 & 0.34 \\
\hline Miscant & 0.39 & 0.66 & & 0.50 \\
\hline Switch & 0.43 & 0.69 & 0.87 & \\
\hline
\end{tabular}

Notes: Renkonen index - left bottom part; Sorensen index - right upper part (for abbreviations, see Fig. 2). ders Coleoptera, Araneae and Hymenoptera. The latter was represented mainly by Formicidae, Apidae and Vespoidea.

The Coleoptera dominated at each study plot; their relative abundance varied from $57.0 \%$ (Contr) to $88.9 \%$ (Miscant) of collected animals. The Hymenoptera proportion ranged from $0.4 \%$ (Miscant) to $20.1 \%$ (Contr) and that of the Araneae from 3.3\% (Switch) to $10.7 \%$ (Contr). The arthropod community structure at Miscant was the most specific. It had an extremely low activity density of Hymenoptera and the extremely high proportion of Coleoptera (88.9\%). The Araneae (3.8\%) and Isopoda (2.6\%) followed it, while the relative abundance of all the other orders in total accounted for only $4.7 \%$.

\section{Spider assemblages}

Forty-nine spider species of 14 families were recorded from the study plots. The most diverse were the families Gnaphosidae (13 species, $26.5 \%$ of the species list) and Lycosidae (12 species, $22.5 \%)$. Species richness of spider assemblages at the study plots decreased in the following way: Contr (31), GrLgMix (23), Switch (18) and Miscant (14 species). Spider individual abundance was the highest at GrLgMix (1655 specimens) and the lowest at Switch (388 specimens) (Appendix, Table 1).

Shannon index of spider diversity was maximal at Contr, but its differences from the indices at GrLgMix and Switch were statistically insignificant (Fig. 3). The evenness grew from Contr to Switch, the Simpson index being statistically lower only at Miscant.

Spider dominant complexes included only two species: Pardosa agrestis and Xerolycosa miniata. Together they accounted 
from $86.4 \%$ (Contr) to $96.4 \%$ (Miscant) of collected spiders at each plot. Other species had the statuses of recedents or subrecedents only. Pardosa agrestis preferred Switch and Miscant with the highest fidelity index at the latter plot, while Xerolycosa miniata was associated with Contr (Fig. 4; Appendix, Table 1). Both species had equal proportions at GrLgMix and their fidelity indices approached zero.

Six recedent species can be regarded as habitat specific within the study site. Zelotes aeneus, Alopecosa cuneata, Phlegra fasciata and Zodarion rubidum chose Contr; Zelotes latreillei and Alopecosa pulverulenta chose GrLgMix, but no specific species were found at Switch or Miscant. Five species (Trochosa ruricola, Thanatus arenarius, Xysticus cristatus, X. kochi and Drassyllus praeficus) occurred at the four study plots. Of these, only Trochosa ruricola showed no habitat specificity, while the others displayed lower or higher preferences for Contr (fidelity index 0.197-0.516).

Seasonal dynamics of dominant species varied depending on the plot (Fig. 5). Pardosa agrestis peaked in late July being most abundant at GrLgMix and Miscant. Xerolycosa miniata was numerous at Contr and GrLgMix from early June to late July. It had one peak at Miscant in early July and then dropped and disappeared at both Miscant and Switch.

Both faunistic and biocenotic similarities of spider assemblages were the highest between Miscant and Switch $\left(\mathrm{K}_{\mathrm{S}}=0.50\right.$, $\mathrm{K}_{\mathrm{R}}=0.87$ ); the lowest were the faunistic similarity between Contr and Switch $\left(\mathrm{K}_{\mathrm{S}}=0.29\right)$ and biocenotic similarity between Contr and Miscant $\left(\mathrm{K}_{\mathrm{R}}=0.39\right)$ (Table 1$)$.

DCA ordination shows the differences between the study plots based on the structure of spider assemblages (Fig. 6): GrLgMix occupies the middle position on Axis 1 between Contr and Miscant; the distances Switch-Miscant and Contr-GrLgMix are approximately equal on Axis 2, but in total, Switch is the most distant from the other study plots. Dominant spiders take middle position at the ordination plot, Pardosa agrestis being closer to Switch and Miscant. The Xerolycosa miniata low abundance at Switch defines the plot's higher extremity on Axis 2. All species included in the analysis are shared between Contr and GrLgMix, leaving the energy crop fields out of the $95 \%$ confidence area.

\section{Discussion}

In the course of our research, 47 spider species were recorded from the four experimental fields of the Bukovyna Agricultural Station. The majority (31) inhabited an abandoned field, while the switchgrass and miscanthus fields were populated by only 14 and 18 species, respectively. Spider individual abundance in the energy crops was also lower, but alpha diversity decreased significantly only in the miscanthus field. Early spring arthropod assemblages showed the similar traits, being the richest in abandoned field and the poorest in the miscanthus one.

Our data are consistent with the results of the long-term miscanthus studies in southeast England (Williams, Feest, 2019). Conclusions on the miscanthus benefits to biodiversity (Jodl et al., 2004; Semere, Slater, 2007) are based on its comparison with other biomass crops and/or investigation of young plantations. Miscanthus was also shown to host least divers and abundant invertebrate communities than switchgrass and abandoned fields in the USA (Snelik, 2018) that corresponds to out observations.

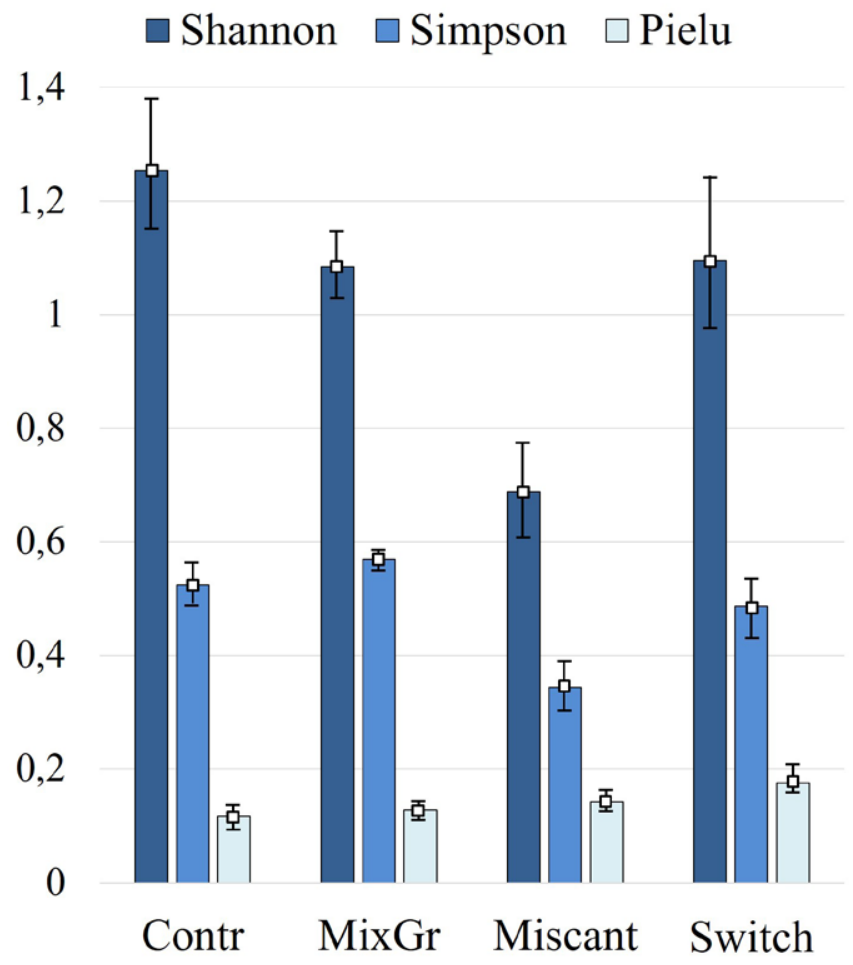

Fig. 3. Alpha-diversity indices of spider assemblages at the study plots. Whiskers indicate min and max bootstrap values (for abbreviations, see Fig. 2).

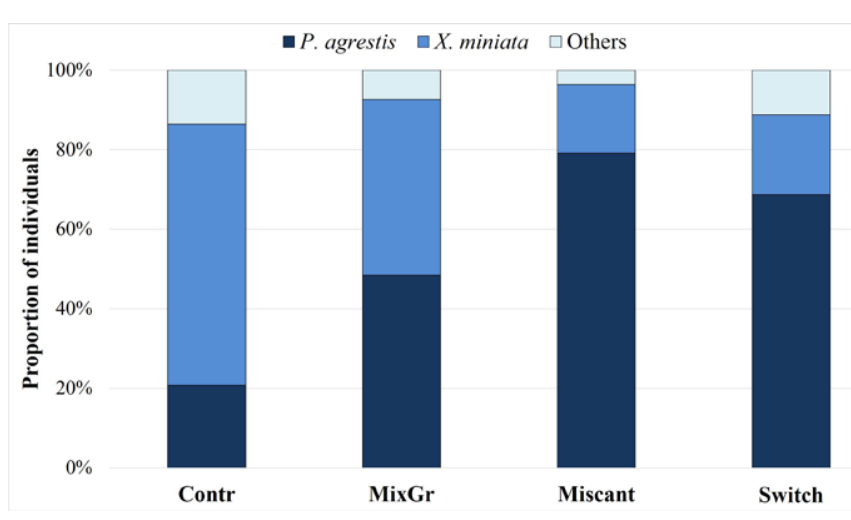

Fig. 4. Dominance structure of spider assemblages at the study plots (for abbreviations, see Fig. 2).

Spiders are known to have a high dispersal capacity; many species colonize cultivated fields from surrounding habitats (Öberg et al., 2008; Benhadi-Marín et al., 2016). Nevertheless, despite the close location and small areas, only Trochosa ruricola was distributed more or less evenly within the four study plots; 18 species preferred the abandoned field and/or grass mixture, while not a single species chose switchgrass, miscanthus or both. All the fields were dominated by two widespread grasslands species, numerous on arable and abandoned lands. Pardosa agrestis is reported to be the main eudominant in grain fields in the south of the East European Plain (Seyfulina, 2010; Zhuravel et 

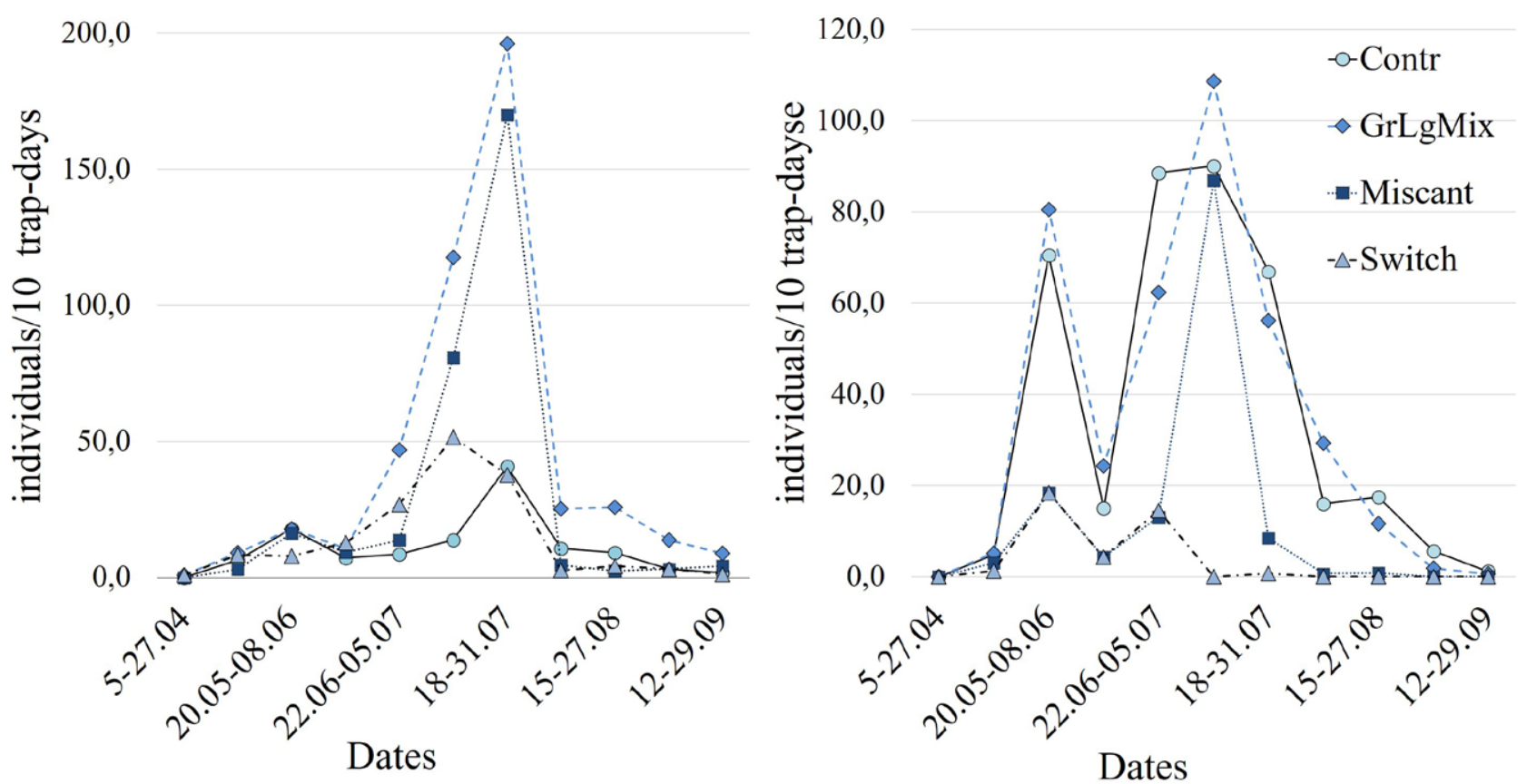

Fig. 5. Seasonal dynamic densities of the dominant spider species (Pardosa agrestis left and Xerolycosa miniata right) at the study plots (for abbreviations, see Fig. 2).

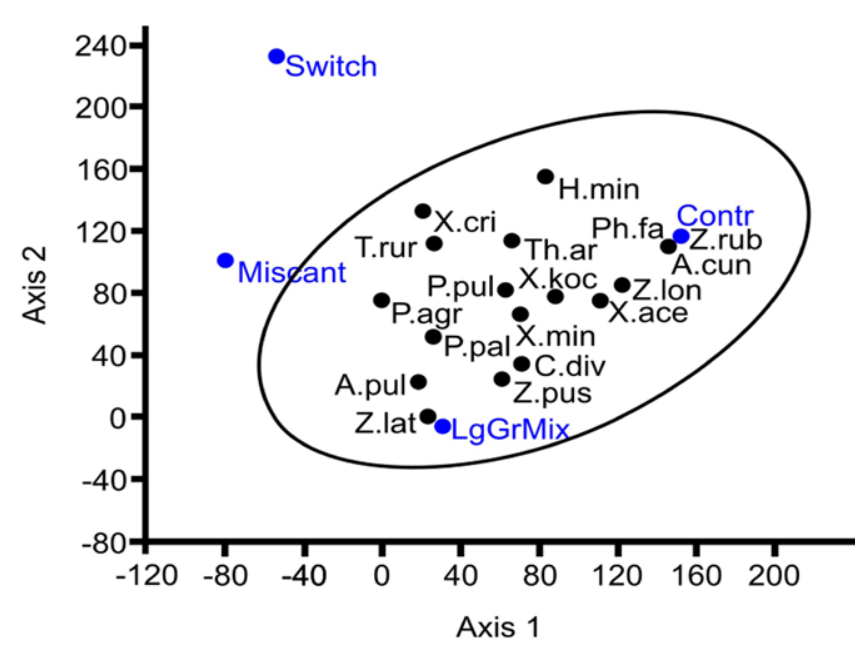

Fig. 6. DCA ordination of the study plots based on spider species composition and individual numbers. A 95\% confidence ellipse is displayed (for abbreviations, see Fig. 2 and Appendix, Table 1).

al., 2012) and a second-rank dominant in the north (Seyfulina, 2005). Interestingly, that its dominance status in adjacent virgin steppes is not higher than recedent (Prokopenko, Savchenko, 2013). The high abundance of Xerolycosa miniata is typical of disturbed lands, like extensively grazed pastures, fallows or burnt grasslands (Prokopenko, Savchenko, 2013; Polchaninova et al., 2016). At our study site, it finds preferable conditions in both abandoned field and grass mixture being not numerous in the energy crops.

Both dominants are photophylous species. In the study year, they reached their maximal abundance in mid or late July and then gradually declined. In the switchgrass and miscanthus, their individual numbers decreased dramatically after the peak due to the change in lighting conditions: grown plants shaded the ground and transformed open grasslands into a dark 'jungle'. For the same reason, Zelotes longipes, a numerous autumnal dry grassland species (Polchaninova et al., 2019), was absent from the energy crops. Seasonal changes in macroclimatic conditions and insufficient fodder are, presumably, the main factors affecting spider communities in biofuel crops (Williams, Feest, 2019).

\section{Conclusion}

Except the dominance structure, spider assemblages of the miscanthus and switchgrass fields differed dramatically from those of the neighbouring grassy habitats. They were poorer in species diversity and individual abundance. An essential depletion of spiders and other arthropods in perennial biofuel crops affects biodiversity in agroecosystems. We recommend preserving small areas of natural or semi-natural vegetation between the cultivated fields for providing ecologically friendly agricultural management.

\section{References}

Benhadi-Marín, J., Pereira, J.A., Bento, A., Sousa, J.P. \& Santos S.A.P. (2016) Biodiversity of spiders in agroecosystems: community structure, conservation and roles as biological control agents. In S.A.P. Santos (Ed.), Natural enemies: Identification, protection strategies and ecological impacts (pp. 43-110). Hauppauge: Nova Science Publishers. 
Blaum, N., Seymour, C., Rossmanith, E., Schwager, M. \& Jeltsch F. (2009) Changes in arthropod diversity along a land use driven gradient of shrub cover in savanna rangelands: identification of suitable indicators. Biodivers. Conserv., 18(5), 1187-1199. DOI: 10.1007/s10531-008-9498-x.

Cole, L.J., McCracken, D.I., Downie, I.S., Dennis, P., Foster, G.N., Waterhouse, A., Murphy, K.J., Griffin, A.L. \& Kennedy M.P. (2005). Comparing the effects of farming practices on ground beetle (Coleoptera: Carabidae) and spider (Araneae) assemblages of Scottish farmland. Biodivers. Conserv. 14(2), 441-460. DOI: 10.1007/s10531-004-6404-z.

Cook, J.H., Beyea, J. \& Keeler K.H. (1991). Potential impacts of biomass production in the United States on biological diversity. Annual Review of Energy and the Environment, 16, 401-431. DOI: 10.1146/annurev. eg.16.110191.002153.

Dauber, J., Cass, S., Gabriel, D., Harte, K., Åström, S., O’Rourke, E. \& Stout J.C. (2015). Yield-biodiversity trade-off in patchy fields of Miscanthus $\times$ giganteus. Global Change Biology Bioenergy, 7, 455-467. DOI: 10.1111/ gcbb.12167.

Dauber, J., Jones, M.B., \& Stout J.C. (2010). The impact of biomass crop cultivation on temperate biodiversity. Global Change Biology Bioenergy, 2(6), 289-309. DOI: 10.1111/j.1757-1707.2010.01058.x.

Eggers, J., Tröltzsch, K., Falcucci, A., Maiorano, L., Verburg, P.H., Framstad E., Louette, G., Maes, D., Nagy, Sz., Ozinga, W. \& Delbaere B. (2009). Is biofuel policy harming biodiversity in Europe? Global Change Biology Bioenergy, 1(1), 18-34. DOI: 10.1111/j.1757-1707.2009.01002.x.

Energy Strategy of Ukraine until 2035 (2017). Security, energy efficiency, competitiveness. The order of Cabinet of Ministers dated. https://www.kmu. gov.ua/en/news/250210653

Groom, M.J., Gray, E.M. \& Townsend P.A. (2008). Biofuels and biodiversity: principles for creating better policies for biofuel production. Conserv. Biol., 22(3), 602-609. DOI: 10.1111/j.1523-1739.2007.00879.x.

Hammer, Ø., Harper, D.A.T. \& Ryan P.D. (2001). PAST: Paleontological Statistics Software Package for Education and Data Analysis. Palaeontology Electronic, 4(1), 1-9. https://palaeo-electronica.org/2001_1/past/past. pdf

Holguin, C.M., Reay-Jones, F.P.F., Frederick, J.R., Adler, P.H., Chong, J.H. \& Savereno A. (2010). Insect diversity in switchgrass grown for biofuel in South Carolina. J. Agric. Urban Entomol., 27(1), 1-19. DOI 10.3954/1523-5475-27.1.1

Jodl, S., Eppel-Hotz, A. \& Kuhn W. (2004). Miscanthus als nachwachsender Rohstoff. Veitshöchheimer Berichte, 77, 1-34.

Jost, L., Chao, A. \& Chazdon R.L. (2011). Compositional similarity and $\beta$ (beta) diversity. In A.E. Magurran \& B.J. Mc Gill (Eds.), Biological diversity: frontiers in measurement and assessment ( pp. 66-84). Oxford: Oxford University Press.

Lewandowski, I., Scurlock, J.M., Lindvall, E. \& Christou M. (2003). The development and current status of perennial rhizomatous grasses as energy crops in the US and Europe. Biomass Bioenergy, 25(4), 335-361. DOI 10.1016/S0961-9534(03)00030-8.

Magurran, A. (1991). Ecological diversity and its measurements. London: Chapman and Hall.

Maloney, D., Drummond, F.A. \& Alford R. (2003). Spider predation in agroecosystems: can spiders effectively control pest population? MAFES Technical Bulletin, 190, 1-32.

Michalko, R., Pekar, S. \& Entling M.H. (2019). An updated perspective on spiders as generalist predators in biological control. Oecologia, 189(1), 21-36. DOI: $10.1007 /$ s00442-018-4313-1.

National Atlas of Ukraine (2007). Kyiv.

Öberg, S., Mayr, S. \& Dauber J. (2008). Landscape effects on recolonisation patterns of spiders in arable fields. Agric. Ecosyst. Environ., 123(1-3), 211-218. DOI: 10.1016/j.agee.2007.06.005.

Pesenko, Y.A. (1982). Principles and methods of quantitative analysis in faunistic researches (in Russian). Moscow: Nauka.
Platen, R., Konrad, J. \& Glemnitz M. (2017). Novel energy crops: an opportunity to enhance the biodiversity of arthropod assemblages in biomass feedstock cultures? International Journal of Biodiversity Science, Ecosystem Services \& Management, 13(1), 162-171. DOI: 10.1080/21513732.2017.1289244.

Polchaninova, N., Savchenko, G., Ronkin, V., Drogvalenko, A. \& Putchkov A (2019). Summer fire in steppe habitats: a long-term effect on vegetation and autumnal assemblages of cursorial arthropods. Hacquetia, 18(2), 213-231. DOI: 10.2478/hacq-2019-0006.

Polchaninova N., Tsurikov, M. \& Atemasov A. (2016). Effect of summer fire on cursorial spider (Aranei) and beetle (Coleoptera) assemblages in meadow steppes of Central European Russia. Hacquetia, 15(2), 113-132. DOI: $10.1515 /$ hacq-2016-0019.

Prokopenko, E.V. \& Savchenko E.Y. (2013). Spiders (Aranei) of agrocoenoses of the Donetsk Region (in Russian). Probl. Ekol. i Okhrany Prirody Tekhnogennogo Reg. Mezhvedomstv. sb. Nauchn. Rabot., 1, 122-133.

Sabluk, V.T., Gryshchenko, O.M., Smirnykh, V.M., Pedos, V.P. \& Suslyk L.O. (2018). Do pests impose a danger to bioenergy crops? (in Ukrainian). Bioenergy, 1, 37-40.

Schaeffer, S., Baxendale, F., Heng-Moss, T., Sitz, R., Sarath, G., Mitchell, R. \& Shearman R. (2011). Characterization of the Arthropod Community Associated with Switchgrass (Poales: Poaceae) in Nebraska. J. Kans. Entomol. Soc., 84(2), 87-104. DOI: 10.2317/JKES100329.1.

Semere, T. \& Slate F.M. (2007) Ground flora, small mammal and bird species diversity in miscanthus (Miscanthus $\times$ giganteus) and reed canarygrass (Phalaris arundinacea) fields. Biomass Bioenergy, 31, 20-29. DOI 10.1016/j.biombioe.2006.07.001

Seyfulina, R.R. (2005). Epigeic spiders (Arachnida, Aranei) in agroecosystems of Moscow region (species composition, spatial distribution, and seasonal dynamics) (in Russian). Russian Journal of Zoology, 84(3), 330-346.

Seyfulina, R.R. (2010). The spider assemblage (Arachnida, Aranei) in agroecosystems of the Kuban Plain: Species composition, spatial distribution, and seasonal dynamics (in Russian). Russian Journal of Zoology, 89(2), 151-166.

Snelick, T.L. (2018). Arthropod Abundance and Diversity in Miscanthus $x$ giganteus, Panicum virgatum, and Other Habitat Types in Southeastern Ohio. Doctoral dissertation, Ohio University.

Stefanovska, Ò.R., Lewis, E.E., Likar, Ya.O., Rakhmetov, D.B. \& Pidlisnyuk V.V. (2011). Herbivorous pests of Miscanthus giganteus. Studying of its potential impact to agrocenosis for second generation biofuel production (in Ukrainian). Karantin i Zahist Roslin, 5, 6-8.

Stefanovska, T.R., Kucherovs'ka, S.V. \& Pidlisniuk V.V. (2012). Agro-ecological risk assessment of cultivation of swissgrass considering the impact of harmful organisms (in Ukrainian). Agroecological Journal, 3, 125-127.

Stöcker, G. \& Bergmann A. (1977). Ein Modell der Dominanzstruktur und seine nwendung. Archiv für Naturschutz und Landschaftforschung, 17, 1-26.

Webb, A. \& Coates D. (2012). Biofuels and biodiversity. Montreal: Secretariat of the Convention on Biological Diversity.

Williams, M.A. \& Feest A. (2019). The effect of Miscanthus cultivation on the biodiversity of ground beetles (Coleoptera: Carabidae), spiders and harvestmen (Arachnida: Araneae and Opiliones). Agric. Sci., 10, 903-917. DOI: 10.4236/as.2019.107069.

WWF Living Planet Report (2016). Risk and resilience in a new era. http:// awsassets.panda.org/downloads/lpr_living_planet_report_2016.pdf

Zhukov, O., Kunah, O.M., Dubinina, Y. \& Novikova V. (2018). The role of edaphic and vegetation factors in structuring beta diversity of the soil macrofauna community of the Dnipro river arena terrage. Ekológia (Bratislava), 37(4), 301-327. DOI: 10.2478/eko-2018-0023.

Zhuravel, M.Y., Lezhenina, I.P., Polchaninova, N.Y. \& Yaremenko V.V. (2012) The use of ground-dwelling arthropods for the monitoring of soil reclamation in oil and gas fields (in Ukrainian). The Kharkov Entomological Society Gazette, 20(4), 5-14. 


\section{Appendix}

Spider species composition and individual abundance at the study plots of the Bukovyna State Agricultural Experimental Station of National Academy of Agrarian Sciences of Ukraine April 5 to September 29, 2016.

\begin{tabular}{|c|c|c|c|c|c|}
\hline \multirow{2}{*}{ Species } & \multirow{2}{*}{ Abbr } & \multicolumn{4}{|c|}{ Study plots } \\
\hline & & Contr & GrLgMix & Miscant & Switch \\
\hline \multicolumn{6}{|l|}{ Fam. Agelenidae } \\
\hline Agelenopsis potteri (Blackwall, 1846) & - & - & - & - & 1 \\
\hline Allagelena gracilens (C. L. Koch,1841) & - & - & 1 & - & - \\
\hline Agelenidae sp. juv. & - & - & - & - & 1 \\
\hline \multicolumn{6}{|l|}{ Fam. Araneidae } \\
\hline Argiope bruennichi (Scopoli, 1772) & - & - & - & - & 1 \\
\hline \multicolumn{6}{|l|}{ Fam. Clubionidae } \\
\hline Clubiona diversa (O. P. Cambridge, 1862) & C. div & 1 & 2 & - & - \\
\hline C. neglecta (O. P. Cambridge, 1862) & - & - & - & - & 1 \\
\hline \multicolumn{6}{|l|}{ Fam. Dysderidae } \\
\hline Harpactea rubicunda (C. L. Koch, 1838) & - & 1 & - & - & - \\
\hline \multicolumn{6}{|l|}{ Fam. Gnaphosidae } \\
\hline Callilepis nocturna (Linnaeus, 1758) & - & 1 & - & - & - \\
\hline Drassodes cupreus (Blackwall, 1834) & - & 1 & - & - & - \\
\hline Drassyllus praeficus (L. Koch, 1866) & D. pre & 5 & 4 & 1 & - \\
\hline D. pusillus (C. L. Koch, 1833) & D. pus & 1 & 3 & - & - \\
\hline Haplodrassus minor (O. P. Cambridge, 1879) & H. min & 2 & - & - & 1 \\
\hline H. signifer (C. L. Koch, 1839) & - & - & 1 & - & - \\
\hline Micaria formicaria (Sundevall, 1831) & - & - & 2 & - & - \\
\hline Zelotes aeneus (Simon, 1878) & Z. aen & 5 & - & - & - \\
\hline Z. apricorum (L. Koch, 1876) & - & - & - & 1 & - \\
\hline Z. latreillei (Simon, 1878) & Z. lat & - & 15 & 1 & - \\
\hline Z. longipes (L. Koch, 1866) & Z. lon & 9 & 3 & - & - \\
\hline Z. petrensis (C. L. Koch, 1839) & - & 1 & - & 1 & - \\
\hline Gnaphosidae sp. juv. & - & 1 & - & - & - \\
\hline \multicolumn{6}{|l|}{ Fam. Linyphiidae } \\
\hline Agyneta rurestris (C. L. Koch, 1836) & - & - & 3 & - & - \\
\hline Diplostyla concolor (Wider, 1834) & - & - & - & - & 1 \\
\hline Nematogmus sanguinolentus (Walck., 1841) & - & - & - & 1 & 1 \\
\hline Trichopterna cito (O. P.-Cambridge, 1873) & - & 1 & - & - & - \\
\hline \multicolumn{6}{|l|}{ Fam. Lycosidae } \\
\hline Alopecosa cuneata (Clerck, 1757) & A. cun & 5 & - & - & - \\
\hline A. farinosa (Herman, 1879) & - & 1 & - & 1 & - \\
\hline A. pulverulenta (Clerck, 1757) & A. pul & 13 & 7 & - & 1 \\
\hline Pardosa agrestis (Westring, 1861) & P. agr & $171 /-0.484$ & $646 / 0.012$ & $417 / 0.303$ & $219 / 0.192$ \\
\hline P. fulvipes (Collett, 1876) & - & - & 1 & - & - \\
\hline P. lugubris (Walckenaer, 1802) & - & 1 & - & - & - \\
\hline P. paludicola (Clerck, 1757) & - & 1 & - & - & - \\
\hline P. palustris (Linnaeus, 1758) & P. pal & 4 & 26 & - & 7 \\
\hline P. prativaga (L. Koch, 1870) & - & - & - & - & 2 \\
\hline P. pullata (Clerck, 1757) & P. pul & 2 & 1 & 1 & - \\
\hline Trochosa ruricola (De Geer, 1778) & T. rur & 10 & 8 & 6 & 8 \\
\hline Xerolycosa miniata (C. L. Koch, 1834) & X. min & $541 / 0.328$ & $559 / 0.014$ & $91 /-0.468$ & $64 /-0.382$ \\
\hline Lycosidae sp. juv. & - & 212 & 338 & 80 & 67 \\
\hline \multicolumn{6}{|l|}{ Fam. Philodromidae } \\
\hline Thanatus arenarius (L. Koch, 1872) & Th. ar & 9 & 4 & 1 & 4 \\
\hline Tibellus oblongus (Walckenaer, 1802) & - & - & 1 & - & - \\
\hline \multicolumn{6}{|l|}{ Fam. Phrurolithidae } \\
\hline Phrurolithus festivus (C. L. Koch,1835) & - & 1 & - & - & - \\
\hline
\end{tabular}


Appendix - continue

\begin{tabular}{|c|c|c|c|c|c|}
\hline \multirow{2}{*}{ Species } & \multirow{2}{*}{ Abbr } & \multicolumn{4}{|c|}{ Study plots } \\
\hline & & Contr & GrLgMix & Miscant & Switch \\
\hline \multicolumn{6}{|l|}{ Fam. Pisauridae } \\
\hline Pisaura mirabilis (Clerck, 1757) & - & - & - & - & 2 \\
\hline \multicolumn{6}{|l|}{ Fam. Salticidae } \\
\hline Evarcha arcuata (Clerck, 1757) & - & - & - & 1 & - \\
\hline Heliophanus auratus (C. L. Koch, 1835) & - & 1 & - & - & - \\
\hline H. flavipes (Hahn, 1832) & - & - & - & - & 1 \\
\hline Phlegra fasciata (Hahn, 1826) & $\mathrm{Ph} . \mathrm{fa}$ & 19 & 1 & - & - \\
\hline Salticidae sp. juv. & - & - & 1 & - & - \\
\hline \multicolumn{6}{|l|}{ Fam. Tetragnathidae } \\
\hline Pachygnatha degeeri (Sundevall, 1830) & - & 1 & - & - & - \\
\hline \multicolumn{6}{|l|}{ Fam. Theridiidae } \\
\hline Robertus arundineti (O. Pickard-Cambridge, 1871) & - & - & 1 & - & - \\
\hline \multicolumn{6}{|l|}{ Fam. Thomisidae } \\
\hline Spiracme striatipes (L. Koch, 1870) & - & 1 & - & - & - \\
\hline Xysticus acerbus (Thorell, 1872) & X. ace & 2 & 1 & - & - \\
\hline X. cristatus (Clerck, 1757) & X. cri & 4 & 1 & 3 & 3 \\
\hline X. kochi (Thorell, 1872) & X. koc & 18 & 12 & 1 & 2 \\
\hline Xysticus sp. juv. & - & 7 & 13 & - & - \\
\hline \multicolumn{6}{|l|}{ Fam. Zodariidae } \\
\hline Zodarion rubidum (Simon, 1914) & Z. rub & 4 & - & - & - \\
\hline Total number of individuals & & 1058 & 1655 & 607 & 388 \\
\hline Total number of families & & 12 & 9 & 6 & 10 \\
\hline Total number of species & & 31 & 23 & 14 & 18 \\
\hline
\end{tabular}

Notes: Contr - Control plot; GrLgMix - Grass-legume mixture; Miscant - miscanthus; Switch - switchgrass; Abbr - abbreviation of the species names; - no data; number of individuals/fidelity index. 